\title{
ADSORPTION OF CADMIUM IONS FROM AQUEOUS SOLUTIONS ON MODIFIED SORBENTS
}

\author{
Evgeniya Shachneva ${ }^{1, *}$, Darya Archibasova ${ }^{1}$
}

https://doi.org/10.23939/chcht12.02.182

\begin{abstract}
Some new modified sorbents based on opoka from Astrakhan region were obtained. A comparative study of the sorption of cadmium ions on the surfaces of the sorbents was made. Also the static adsorption isotherm of substances from aqueous solutions was studied. The change of enthalpy, isobaric-isothermal potential and entropy of sorption and kinetics of cadmium ions sorption from water solutions were calculated. The results of the study can be used for the water purification from cadmium ions.
\end{abstract}

Keywords: sorbent, sorption, flocculants, heavy toxic elements, cadmium, water purification.

\section{Introduction}

Heavy metals are among the most common and toxic pollutants that impact the most harmful effect on the human body and biological objects. There are many different ways of penetrating of this class of substances into water objects. The metals contained in water deteriorate the environmental biocenose of water objects and water quality. For instance, cadmium is one of the most toxic heavy metals therefore the Russian SanPiN refers it to the $2^{\text {nd }}$ class of danger (that means "highly dangerous substances").

Certain amounts of cadmium are also in the air. According to foreign data the cadmium concentration in the air of the countryside is $0.1-5.0 \mathrm{ng} / \mathrm{m}^{3}$, in cities $2-15 \mathrm{ng} / \mathrm{m}^{3}$, and in industrial areas - from 15 to $150 \mathrm{ng} / \mathrm{m}^{3}$. These figures can be explained by the fact that many coals contain cadmium as an impurity and, when it is burned by thermal power plants, it enters the atmosphere, where a large part of it is deposited on the soil.

The wide use of mineral fertilizers increases the accumulation of cadmium in soil. In natural conditions cadmium enters the groundwaters due to leaching of nonferrous metals as well as the decomposition of aquatic

\footnotetext{
${ }^{1}$ Astrakhan State University,

1, Area Shaumya, 414000 Astrakhan, Russia

evgshachneva@yandex.ru

(C) Shachneva E., Archibasova D., 2018
}

plants and organisms that are capable to accumulate it. In recent decades the anthropogenic factor of cadmium pollution of natural waters is becoming prevalent.

Cadmium is present in water in the soluble form (for example, cadmium sulfate, chloride, nitrate) or in the form of suspended particles as a part of organo-mineral complexes. Ore-dressing factories, non-ferrous metals plants, chemical and other industrial enterprises are making the main contribution to cadmium emissions into nature nowadays. The cadmium content in water is significantly affected by $\mathrm{pH}$ of the water medium and sorption processes.

On entering the sea and fresh waters, dissolved cadmium deposits are accumulated in the bottom sediments. Cadmium exercises its toxic effect at very low concentrations. Its excess inhibits the synthesis of DNA, proteins and nucleic acids, affects the activity of enzymes, breaks the assimilation and exchange of other trace elements $(\mathrm{Zn}, \mathrm{Cu}, \mathrm{Se}, \mathrm{Fe})$, that can cause their deficiency. Natural sources of entering cadmium into living organism include food (about 90-95\%), water (5-10\%) and air (about $1 \%$ ). MPC of cadmium for drinking water is $0.01 \mathrm{mg} / \mathrm{dm}^{3}$, for long-term irrigation of agricultural soils and water objects $-0.005 \mathrm{mg} / \mathrm{dm}^{3}$.

In addition, the lethal dose for humans is $150 \mathrm{mg} / \mathrm{kg}$ of body weight in $1.5 \mathrm{~h}$, the lethal dose for dogs $-150-600 \mathrm{mg} / \mathrm{kg}$, mice $-50-100 \mathrm{mg} / \mathrm{kg}$, rabbits $300-500 \mathrm{mg} / \mathrm{kg}$. The cadmium content in blood and urine at the concentration of $0.02 \mathrm{mg} / \mathrm{dm}^{3}$ is a proof of its entering at toxic doses. It is able to accumulate in the liver, kidneys, pancreas and thyroid glands. The negative influence of the metal also affects the plants, so the concentration of cadmium in water of $28 \mathrm{mg} / \mathrm{dm}^{3}$ when watering harms sugar beet, but the concentration of $50 \mathrm{mg} / \mathrm{dm}^{3}$ is toxic to all kinds of plants.

The negative effect of cadmium is also observed in different plants and enterprises. For instance, the $1-5 \mathrm{mg} / \mathrm{dm}^{3}$ concentration of cadmium has the harmful effect on sewage treatment facilities, and the content of $5.2 \mathrm{mg} / \mathrm{dm}^{3}$ of the metal reduces wastewater purification effect on percolator filters. After precipitation and filtration of water the cadmium content is reduced by only 
$60 \%$ in plumbing. The biological purification of wastewaters removes $30-80 \%$ of cadmium. Chemical treatment of wastewaters from cadmium is carried out by adding alkali. At the enterprises of ferrous metallurgy the chemical purification of wastewaters from cadmium with the use of lime reaches $98.93 \%$. The same effect of wastewater treatment from cadmium by reverse osmosis is 98-99\%, active carbon adsorption - $99.7 \%$, but cadmium content with the application of precipitation, clarification and filtration through sand can be reduced from 0.7 to $0.08 \mathrm{mg} / \mathrm{dm}^{3}$.

Thus we can make a conclusion that heavy metals are serious polluters of the environment, that impact the most harmful effect on the human body, animals, plants as well as on the processes of self-purification of water objects and the work of treatment facilities. And due to their wide use in different types of industries and human activities, the considered topic and the researches of this field is undoubtedly relevant today [1-14].

\section{Experimental}

A method of producing a sorbent SV-1-A. $100 \mathrm{~g}$ of Portland cement 500, $10 \mathrm{~g}$ of micronized manganese dioxide $\left(\mathrm{MnO}_{2}\right), 25 \mathrm{~cm}^{3}$ of $10 \%$ solution of sodium chloride are added to $100 \mathrm{~g}$ of finely divided opoka with approximately $0.01 \mathrm{~mm}$ in diameter particles (the deposit is village Kamenniy Yar of Astrakhan region). The resulting mixture is thoroughly stirred. The obtained mass is allowed to dry to the point at which the granules may be formed from it. The granules are dried at the temperature of 373-378 K, and then the product should be calcified for 3-4 days. The resulting material is allowed to remain in water as long as the reaction relative to a chloride ion will be negative and then it is dried at $373-378 \mathrm{~K}$.

To create a sorbent with a large number of micropores in a mixture of "opoka-Portland cement 500pyrolusite" a solution of sodium chloride was added. After washing the sodium chloride from the sorbent the finished porous material is formed. It has a high sorption capacity and simultaneously high strength. The reason for introducing pyrolusite into the sorbent is to provide a sorbent which has oxidizing properties to low molecular weight organic and inorganic compounds, as well as to a large set of microorganisms [14].

A method of producing a sorbent $S V-1-A 2.100 \mathrm{~cm}^{3}$ of flocculent Z-92 is added to $100 \mathrm{~g}$ of finely divided sorbent SV-1-A with approximately $0.01 \mathrm{~mm}$ in diameter particles. The resulting solution is thoroughly mixed and allowed to settle, the remaining liquid is decanted and then $500 \mathrm{~cm}^{3}$ of distilled water is added to the mixture under constant stirring. The procedure is repeated once more, and then the sorbent is left for an hour. The resulting adsorbent is dried in a thin layer at the temperature of 323-333 K under constant stirring.

A method of producing a sorbent $S V-1-A 3.100 \mathrm{~cm}^{3}$ of flocculent A-1510 is added to $100 \mathrm{~g}$ of finely divided sorbent SV-1-A with approximately $0.01 \mathrm{~mm}$ in diameter particles. The resulting solution is thoroughly mixed and allowed to settle, the remaining liquid is decanted and then $500 \mathrm{~cm}^{3}$ of distilled water is added to the mixture under constant stirring. The procedure is repeated once more, and then the sorbent is left for an hour. The resulting adsorbent is dried in a thin layer at the temperature of 323-333 K under constant stirring.

Data obtained for the construction of the calibration curve. $0 ; 0.1 ; 0.2 ; 0.5 ; 1.0 ; 1.5 ; 2.0 ; 2.5 ; 3.0$; $5.0 \mathrm{~cm}^{3}$ of a cadmium salt of the $1 \cdot 10^{-3} \mathrm{M}$ concentration were added into a series of 10 test tubes of $20 \mathrm{~cm}^{3}$ volumes, then $4 \mathrm{~cm}^{3}$ of an organic reagent PAR (4-(2pyridylazo)resorcinol) was added into each solution in the test tubes, after that the resulting solutions were led to $20 \mathrm{~cm}^{3}$ volumes with distilled water. The obtained solutions were mixed and their optical densities were measured at $530 \mathrm{~nm}$ in a cuvette of $0.5 \mathrm{~cm}$ in thickness relative to distilled water. The calibration curve was constructed according to the measurement results.

The study of cadmium ions adsorption on sorbents $S V-1-A 2$ and SV- $1-A 3.0 ; 0.1 ; 0.2 ; 0.5 ; 1.0 ; 1.5 ; 2.0 ; 2.5$; $3.0 ; 5.0 \mathrm{~cm}^{3}$ of a cadmium salt of the $1 \cdot 10^{-3} \mathrm{M}$ concentration were added into a series of 10 test tubes of $20 \mathrm{~cm}^{3}$ volumes, then the resulting solutions were led to $20 \mathrm{~cm}^{3}$ volumes with distilled water. $1 \mathrm{~g}$ of the sorbent was put to each resulting solutions, the obtained mixtures were shaken for $3 \mathrm{~min}$ each, then they were allowed to precipitate and at last they were centrifuged at the velocity of 3000 revolutions per minute. Then $4 \mathrm{~cm}^{3}$ of an organic reagent PAR (4-(2-pyridylazo)resorcinol) was added into each solution in the test tubes. The obtained solutions were mixed and their optical densities were measured at $530 \mathrm{~nm}$ in a cuvette of $0.5 \mathrm{~cm}$ in thickness relative to distilled water. The experiments were carried out at three different temperatures: 277, 298, and $313 \mathrm{~K}$.

The study of the kinetics of cadmium ions sorption on sorbents $S V-1-A 2$ and $S V-1-A 3.20 \mathrm{~cm}^{3}$ of cadmium solution of $1 \cdot 10^{-3} \mathrm{M}$ concentration was added to the $500 \mathrm{~cm}^{3}$ flask, and then the resulting solution was adjusted to $500 \mathrm{~cm}^{3}$ by distilled water. $20 \mathrm{~g}$ of finely divided sorbent was added to this solution while switching on a stopwatch, then the mixture was stirred quickly. The resulting solutions were studied at three different temperatures: 298, 277 and $313 \mathrm{~K}$. In an appropriate time intervals the muddy samples were taken which were filtered through a glass filter or were centrifuged. Sampling was carried out at regular intervals up to $30 \mathrm{~min}$. Then $4 \mathrm{~cm}^{3}$ of an organic reagent PAR (4-(2pyridylazo)resorcinol) was added into each solution in the 
test tubes. The obtained solutions were mixed and their optical densities were measured at $530 \mathrm{~nm}$ in a cuvette of $0.5 \mathrm{~cm}$ in thickness relative to distilled water.

\section{Results and Discussion}

The dependence of the optical density on the concentration of $\mathrm{Cd}^{2+}$ is shown in Figs. 1, 2 .

According to the calibration curve, the results of experiments were used to determine the equilibrium concentrations of the studied substances. The sorption

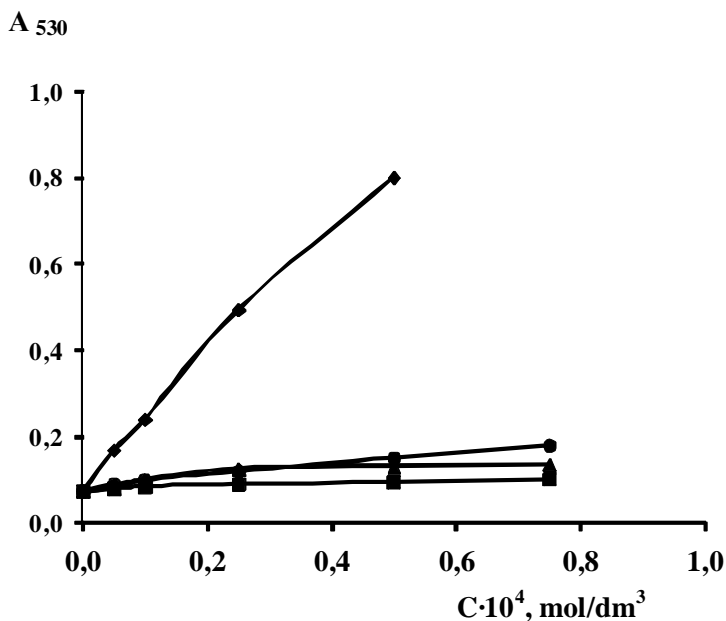

Fig. 1. The dependence of the optical density on the concentration of Cd(II) (sorbent SV-1-A2)

before sorption $(\mathrm{U})$ and after sorption at $277 \mathrm{~K}(\boldsymbol{\Delta})$; $298 \mathrm{~K}(\boldsymbol{\bullet}) ; 313 \mathrm{~K}(\bullet)$ isotherms were built in coordinates "sorption $(\Gamma)-$ equilibrium concentration [c]". Sorption $(\Gamma)$ was calculated according to Eq. (1):

$$
\Gamma=\frac{\left(C_{0}-[C]\right) \cdot M \cdot V}{1000 \cdot m}
$$

where $\Gamma-$ the value of sorption, $\mathrm{g} / \mathrm{g} ; C_{0}-$ the initial concentration of solute, $\mathrm{mol} / \mathrm{dm}^{3} ; V$ - volume of the studied solution, $\mathrm{cm}^{3} ;[C]-$ the residual (equilibrium) concentration of sorbate, $\mathrm{mol} / \mathrm{dm}^{3} ; M-$ molar (or atomic) weight of sorbate, $\mathrm{g} / \mathrm{mol} ; m$ - mass of sorbent, $\mathrm{g}$.

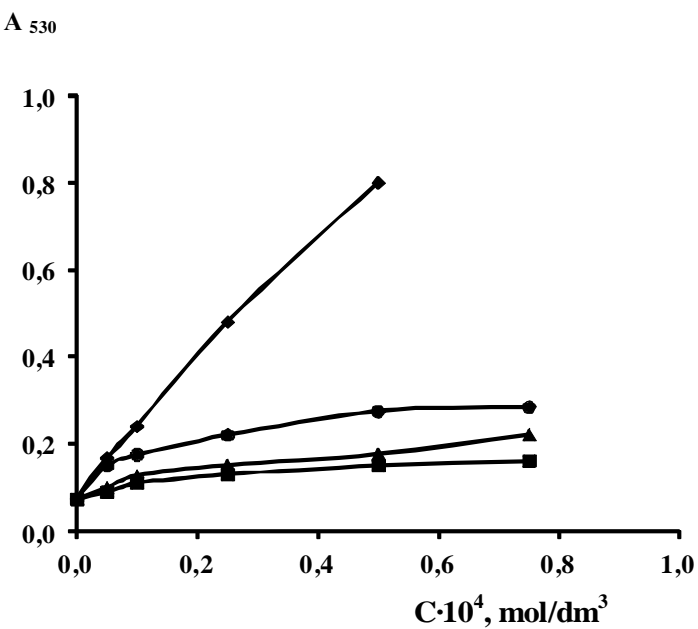

Fig. 2. The dependence of the optical density on the concentration of $\mathrm{Cd}(\mathrm{II})$ (sorbent SV-1-A3)

before sorption $(\mathrm{U})$ and after sorption at $277 \mathrm{~K}(\boldsymbol{\Delta})$; $298 \mathrm{~K}(\boldsymbol{\bullet}) ; 313 \mathrm{~K}(\bullet)$

Table 1

The main characteristics of the sorption of cadmium ions on the SV-1-A2 and SV-1-A3 $\left(n=6, P=0.95, t_{p}=2.57\right)$

\begin{tabular}{|c|c|c|c|}
\hline \multirow{2}{*}{ Defining characteristics } & \multirow{2}{*}{ Temperature, $\mathrm{K}$} & \multicolumn{2}{|c|}{ Sorbents } \\
\hline & & SV-1-A2 & SV-1-A3 \\
\hline \multirow{3}{*}{ Sorption constants } & 277 & $4.17 \pm 0.40$ & $2.47 \pm 0.25$ \\
\hline & 298 & $4.44 \pm 0.40$ & $1.34 \pm 0.10$ \\
\hline & 313 & $1.60 \pm 0.10$ & $0.30 \pm 0.03$ \\
\hline \multirow{3}{*}{$-\Delta G, \mathrm{~kJ} / \mathrm{mol}$} & 277 & $28.62 \pm 2.80$ & $34.26 \pm 3.00$ \\
\hline & 298 & $28.74 \pm 2.80$ & $35.07 \pm 3.50$ \\
\hline & 313 & $31.27 \pm 3.00$ & $49.36 \pm 5.00$ \\
\hline \multicolumn{2}{|l|}{$-\Delta \mathrm{H}, \mathrm{kJ} / \mathrm{mol}$} & $5.08 \pm 0.50$ & $2.55 \pm 0.25$ \\
\hline \multirow{3}{*}{$-\Delta S, \mathrm{~J} \cdot \mathrm{mol} / \mathrm{K}$} & 277 & $96.02 \pm 9.60$ & $114.55 \pm 11.00$ \\
\hline & 298 & $96.42 \pm 9.60$ & $117.60 \pm 11.00$ \\
\hline & 313 & $99.88 \pm 9.80$ & $157.62 \pm 15.00$ \\
\hline \multirow{3}{*}{ Sorbent capacity $\left(\Gamma_{\infty}\right), \mathrm{Mg} / \mathrm{g}$} & 277 & $66.67 \pm 7.00$ & $62.50 \pm 6.00$ \\
\hline & 298 & $100.00 \pm 10.00$ & $83.33 \pm 8.00$ \\
\hline & 313 & $50.00 \pm 5.00$ & $50.00 \pm 5.00$ \\
\hline
\end{tabular}




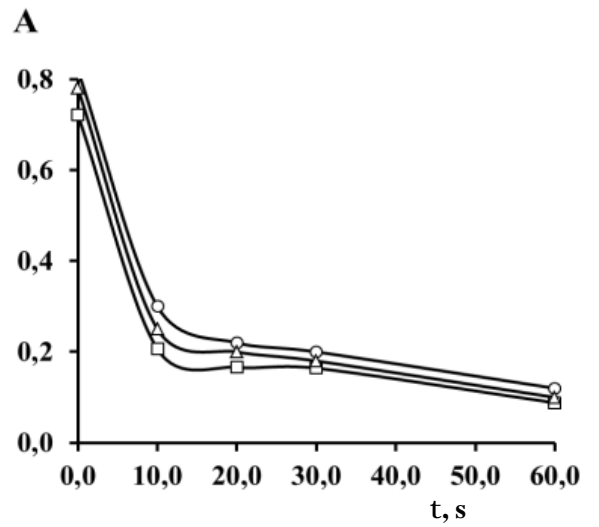

Fig. 3. Sorption kinetics isotherms of cadmium ions by sorbent SV-1 A2 at $277 \mathrm{~K}(\Delta) ; 298 \mathrm{~K}(\square) ; 313 \mathrm{~K}(\mathrm{O})$

Sorption isotherms were recalculated into the Langmuir equation isotherms of straightforward form, which were used to calculate the sorption constants $(K)$ and the value of limiting sorption $\left(\Gamma_{\infty}\right)$ at 277,298 and $313 \mathrm{~K}$. The enthalpy change $(\Delta H)$ and the isobaricisothermal potential $(\Delta G)$ were calculated by using the values of sorption constants, and at last the value of the entropy change $(\Delta S)$ was calculated (Eqs. (2)-(4)):

$$
\begin{array}{r}
\Delta H=\frac{R T_{i} T_{k} \ln \frac{K_{i}}{K_{k}}}{T_{i}-T_{k}} \\
\Delta G_{i}=-R T_{i} \ln K_{i} \\
\Delta S_{i}=\frac{\Delta H-\Delta G_{i}}{T_{i}}
\end{array}
$$

The results of experiments and calculations are shown in Table 1. Analysis of the results leads to the conclusion that the cadmium ions sorption on the studied sorbents is very active. Negative values of the enthalpy and the isobaric-isothermal potential demonstrate the spontaneous nature of the sorption process. These results suggest the formation of strong adsorption complexes, while the sorbent capacity in relation to the heavy toxic metals is high enough, that allows to extract the large quantities of cadmium from water at a wide temperature range.

\subsection{The Kinetics of Cadmium Ions Sorption on Sorbents SV-1-A2 and SV- 1-A3}

The study of the kinetics of sorption of cadmium ions included the construction of sorption kinetics isotherms by measuring optical densities of the solutions at different time intervals, the calculation of the sorption rate constants, the change in entropy of the activated
A

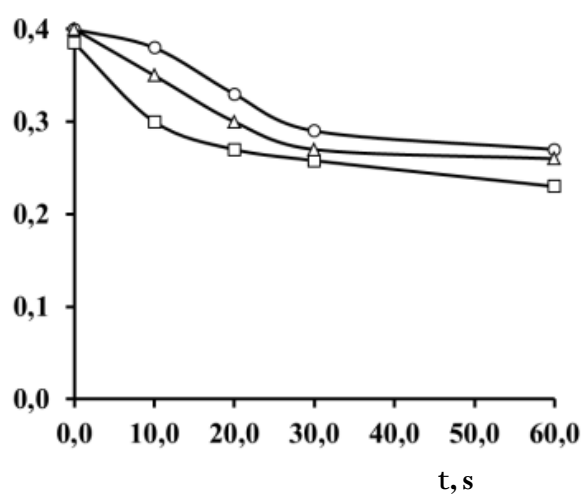

Fig. 4. Sorption kinetics isotherms of cadmium ions by sorbent SV-1 A3 at $277 \mathrm{~K}(\Delta) ; 298 \mathrm{~K}(\square) ; 313 \mathrm{~K}(0)$

complex formation $(\Delta S)^{\#}$, the activation energy of the formation of the adsorption complex $\left(E_{a c t}\right)$. The isotherms of sorption kinetics in the coordinates "optical density $(A)$ - time $(\tau)$ " are presented in Figs. 3, 4.

The time for establishing the equilibrium of sorption is a necessary characteristic of describing the equilibrium processes, and the value of the entropy change of activation of the formation of the activated complex is necessary to establish the mechanisms of sorption of cadmium ions by the examined sorbents.

According to the research the sorption kinetics constants of cadmium ions on the modified sorbents at temperatures of 277,298 and $313 \mathrm{~K}, S^{\#}$ and $E_{a c t}$, were calculated:

$$
K=\frac{1}{\tau} \ln \frac{A_{0}}{A_{i}}
$$

where $A_{0}$ - the initial optical density; $A_{i}$ - optical density of the solution at the moment of time $\tau ; \tau$ - time, s.

According to the Arrhenius curves in the coordinates " $\ln K-1 / T$ " the values of activation energy of sorption kinetics $\left(E_{a c t}\right)$ was calculated and the entropy change of sorption complex formation $\left(S^{\#}\right)$ was also calculated using the Eyring equation:

$$
\ln P Z_{0}=10.36+\ln T+\frac{\Delta S^{\#}}{R}
$$

In Eq. (6) $P Z_{0}-$ a pre-exponential factor in the Arrhenius equation, $\Delta S^{\#}$ - the entropy change of activation of activated complex formation, $R-$ gas constant, $T-$ temperature.

The results of calculations of the sorption kinetics constants, $E_{a c t}$ and $\Delta S^{\#}$, of cadmium ions on the modified sorbents are shown in Table 2.

Almost all studied sorption processes can be characterized by fairly steep initial line segment of sorption 
kinetics isotherms. As can be seen from the results of experiments, sorption is rapid enough, and finishes in three minutes, that means that the sorbate is almost completely adsorbed on the examined sorbents.

\subsection{The results of $\mathbf{W}$ ater Purification from Cadmium Ions on Sorbents SV-1- A2 and SV-1-A3}

The experiments of water purification from cadmium ions were carried out. Contaminants were added into the initial water in the amounts shown in Table 3 . The cleaning efficiency was calculated using the formula:

$$
E=\frac{C_{0}-C}{C_{0}} \cdot 100 \%
$$

where $E$ - efficiency of cleaning, \%; $C_{0}$ - the initial concentration, $\mathrm{mol} / \mathrm{dm}^{3} ; C-$ the residual concentration, $\mathrm{mol} / \mathrm{dm}^{3}$.

The calculated results of water purification efficiency from cadmium ions on sorbents SV-1-A2 and SV-1-A3 are shown in Table 3.

Table 2

The thermodynamic characteristics of sorption kinetics

of cadmium ions on sorbents SV-1-A2 and SV-1-A3 $\left(n=6, P=0.95, t_{p}=2.57\right)$

\begin{tabular}{|c|c|c|c|}
\hline \multirow{2}{*}{ Defining characteristics } & \multirow{2}{*}{ Temperature, $\mathrm{K}$} & SV-1-A2 & SV-1-A3 \\
\cline { 2 - 4 } & 277 & $3.43 \pm 0.30$ & $0.65 \pm 0.06$ \\
\hline \multirow{2}{*}{$\begin{array}{c}\text { Rate constants } K \cdot 10^{-2} \mathrm{~s}^{-1} \text { at } \\
\text { temperatures, } \mathrm{K}\end{array}$} & 298 & $3.64 \pm 0.40$ & $0.84 \pm 0.08$ \\
\cline { 2 - 4 } & 313 & $3.20 \pm 0.30$ & $0.47 \pm 0.04$ \\
\hline$E_{\text {act }} \mathrm{KJ} / \mathrm{mol}$ & $277-313$ & $5.15 \pm 0.50$ & $2.49 \pm 0.20$ \\
\hline \multirow{3}{*}{$-\Delta S^{\#}, \mathrm{~J} / \mathrm{mol} \cdot \mathrm{K}$} & 277 & $2.35 \pm 0.20$ & $2.36 \pm 0.20$ \\
\cline { 2 - 4 } & 298 & $2.36 \pm 0.20$ & $2.37 \pm 0.20$ \\
\cline { 2 - 4 } & 313 & $2.34 \pm 0.20$ & $2.35 \pm 0.20$ \\
\hline
\end{tabular}

Table 3

The efficiency of water purification from cadmium ions on sorbents SV-1-A2 and SV-1-A3

$$
\left(n=6, P=0.95, t_{p}=2.57\right)
$$

\begin{tabular}{|c|c|c|c|c|c|c|c|}
\hline \multirow{3}{*}{ Sorbent } & \multirow{3}{*}{$\begin{array}{l}\text { Initial } \\
\text { concentration } \cdot 10^{4} \\
\mathrm{~mol} / \mathrm{dm}^{3}\end{array}$} & \multirow{2}{*}{\multicolumn{3}{|c|}{$\begin{array}{c}\text { Concentration after sorption } 10^{4} \text {, } \\
\mathrm{mol} / \mathrm{dm}^{3}\end{array}$}} & \multirow{2}{*}{\multicolumn{3}{|c|}{ Purification efficiency, $\%$}} \\
\hline & & & & & & & \\
\hline & & 277 & 298 & 313 & 277 & 298 & 313 \\
\hline \multirow{10}{*}{ SV-1-A2 } & 0 & 0 & 0 & 0 & 0 & 0 & 0 \\
\hline & 0.05 & 0.010 & 0.015 & 0.030 & 80.00 & 70.00 & 20.00 \\
\hline & 0.10 & 0.012 & 0.030 & 0.040 & 88.00 & 70.00 & 30.00 \\
\hline & 0.25 & 0.013 & 0.050 & 0.070 & 94.80 & 80.00 & 62.00 \\
\hline & 0.50 & 0.015 & 0.055 & 0.095 & 97.00 & 89.00 & 80.00 \\
\hline & 0.75 & 0.016 & 0.060 & 0.100 & 97.87 & 92.00 & 86.00 \\
\hline & 1.00 & 0.018 & 0.065 & 0.105 & 98.20 & 93.50 & 89.00 \\
\hline & 1.25 & 0.020 & 0.070 & 0.110 & 98.40 & 94.40 & 90.40 \\
\hline & 1.50 & 0.025 & 0.075 & 0.120 & 98.33 & 95.00 & 91.33 \\
\hline & 2.50 & 0.030 & 0.080 & 0.130 & 98.80 & 96.8 & 100.00 \\
\hline \multirow{10}{*}{ SV-1-A3 } & 0 & 0 & 0 & 0 & 0 & 0 & 0 \\
\hline & 0.05 & 0.018 & 0.030 & 0.045 & 64.00 & 40.00 & 10.00 \\
\hline & 0.10 & 0.030 & 0.050 & 0.060 & 70.00 & 50.00 & 40.00 \\
\hline & 0.25 & 0.050 & 0.090 & 0.080 & 80.00 & 64.00 & 68.0 \\
\hline & 0.50 & 0.055 & 0.095 & 0.150 & 89.00 & 81.00 & 70.00 \\
\hline & 0.75 & 0.060 & 0.100 & 0.165 & 92.00 & 86.67 & 78.00 \\
\hline & 1.00 & 0.061 & 0.120 & 0.180 & 93.90 & 88.00 & 82.00 \\
\hline & 1.25 & 0.063 & 0.140 & 0.190 & 94.96 & 88.80 & 84.80 \\
\hline & 1.50 & 0.065 & 0.150 & 0.195 & 95.67 & 90.00 & 87.00 \\
\hline & 2.50 & 0.070 & 0.160 & 0.200 & 97.20 & 93.60 & 92.00 \\
\hline
\end{tabular}




\section{Conclusions}

The obtained results clearly demonstrate the high efficiency of using new modified sorbents SV-1-A2 and SV1-A3, created on the basis of opoka from Astrakhan region, for water purification from toxic heavy metals such as cadmium, with a purification efficiency of up to $98 \%$.

The decisive role of the possible mechanisms of the substances sorption belongs to the electronic structure of the solid and the adsorbed particles on it. If it is true, the behavior of the system under study can be supposed. The sorption methods of concentration based on the absorption of dissolved substances by solid absorbers, present a great variety of sorption mechanisms: adsorption, absorption, chemisorption and capillary condensation, which in practice are usually combined with each other. Thus, chemisorption is usually followed by adsorption. Adsorption and chemisorption techniques are commonly used for concentration of heavy metals. The basis theory of adsorption considers that only those compounds which form a chemical bond with the surface more strongly than hydrogen can displace water from the surface of the oxide and can also be adsorbed. Also the molecular size is one of the important characteristics in an adsorption theory. The energy gain at the transition from the solution volume to the surface depends not only on the strength of the resulting chemical bond, but also on how much of the solvent molecules are displaced by one molecule of adsorbate. The degree of molecules association, the tendency to micelle formation, attractions and other interactions may vary depending on the change in the molecule size. The resulting sorbents have a high sorption capacity to the metal ions, that's why it can be assumed that the adsorption is carried out through the formation of chemical bonds between the sorbate and the sorbent, i.e. there is a metal cation chemisorption. Chemisorption of a metal cation most likely occurs through a donor-acceptor mechanism to form a covalent bond and / or as a result of dipole-dipole interaction between the metal cation and the sorbent $[15,16]$.

An analysis of the experimental and theoretical study of adsorption leads to the following conclusion: opoka of Astrakhan region and sorbents based on it contain active sites, such as groups $\equiv \mathrm{Si}-\mathrm{OH}$

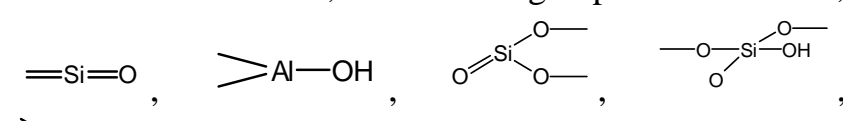
$-\mathrm{Si}=\mathrm{O}--\mathrm{H}_{2} \mathrm{O}, \quad=\mathrm{Al}-\mathrm{OH}-\mathrm{OH}_{2}$, i.e. there is a wide opportunity to adsorption by different mechanisms.

The results obtained in the study clearly demonstrate the high efficiency of the use of modified sorbents created on the basis of opoka from Astrakhan region for water purification from toxic heavy metals such as cadmium. The water from the network of domestic water supply as well as one of the industrial use can be used for purification. The information above suggests the expediency of using the natural resources of Astrakhan region - opoka and sorbents based on it for solving some of the environmental problems associated with purification of natural and waste waters from toxic heavy metals such as cadmium.

\section{References}

[1] Alykov N. et al.: Prirodnye Mineralnye Resursy i Problemy Okruzhaushei Sredy Astrakhanskoi Oblasti, Astrakhan Univ., Astrakhan 2005.

[2] Omidi F., Behbahani M., Kalate Bojdi M., Shahtaheri S.: J. Magn. Magn. Mater., 2015, 395, 213.

https://doi.org/10.1016/j.jmmm.2015.07.093

[3] Chen L., Lü L., Shao W., Luo F.: J. Chem. Eng. Data, 2011, 56, 1059. https://doi.org/10.1021/je101037x

[4] Kostin A., Mostalygina L., Bukhtoyarov O.: Prot. Met. Phys. Chem. Surf., 2015, 51, 477.

https://doi.org/10.7868/S0044185615050174

[5] Zamani A., Shokri R., Yaftian M., Parizanganeh A.: Int. J. Environ. Sci. Technol., 2013, 10, 93.

https://doi.org/10.1007/s13762-012-0107-x

[6] Kostin A., Mostalygina L., Bukhtoyarov O.: Prot. Met. Phys. Chem. Surf., 2015, 51, 5, 773.

https://doi.org/10.1134/S2070205115050172

[7] Bian Y., Bian Z., Zhang J. et al.: Chinese J. Chem. Eng., 2015 ,

23, 1705. https://doi.org/10.1016/j.cjche.2015.08.031

[8] Mohammadi M., Ghaemi A., Asadollahzadeh M. et al.:

Desalination Water Treat., 2015, 53, 149.

https://doi.org/10.1080/19443994.2013.836990

[9] Kumar R., Chawla J., Kaur I.: J. Water Health, 2015, 13, 18. https://doi.org/10.2166/wh.2014.024

[10] Barka N., Ouzaouit K., Abdennouri M. et al.: Desalination Water Treat., 2012, 43, 8. https://doi.org/10.1007/s12011-015-0538-6

[11] Mamedova S.: Eur. J. Anal. Appl. Chem., 2015, 1, 23.

[12] Ben Bouabdallah A., Djelali N.: Revue Roumaine de Chimie,

2015, 60, 321.

[13] Zeynalov R., Tatayeva S., Atayeva N.: Analitika i Control, 2013, 17, 89.

[14] Demirbas A.: J. Hazard. Mat., 2004, 109, 221.

[15] Shachneva E. et al:: Ecologia i Promyshlennost Rossii, 2010, 8, 20.

[16] Nechayev E.: Khemosorbtsiya Organicheskikh Veshchestv na

Oksidakh i Metallakh. Kharkov. Univ., Kharkov 1989.

Received: February 17, 2017 / Revised: March 09, 2017 / Accepted: May 29, 2017

\section{АДСОРБЦІЯ КАДМІЮ 3 ВОДНИХ РОЗЧИНІВ НА МОДИФІКОВАНИХ СОРБЕНТАХ}

Анотація. Одержано нові модифіковані сорбенти на основі опок Астраханської області. Проведено порівняння сорбиї кадмію на вказаних сорбентах. Вивчено ізотерми статичної сорбиії речовин з водних розчинів, розраховані зміни ентальпії, ізобарно-ізотермічного потенціалу та ентропії сорбиіі. Розрахована кінетика сорбиії йонів кадмію з водних розчинів. Показано, що результати досліджень можуть бути використані для очищення води від йонів кадмію.

Ключові слова: сорбент, сорбчія, флокулянти, важкі токсичні елементи, кадмій, очщщення води. 